\title{
Pelatihan Pemaknaan dan Pembacaan Ayat-ayat Alquran Untuk Menurunkan Tingkat Stres Mahasiswa yang Sedang Mengerjakan Skripsi ${ }^{1}$
}

\author{
Hafiz Anshori, Shanty Komalasari² \\ Universitas Islam Negeri (UIN) Antasari Banjarmasin
}

\begin{abstract}
Students' pressures while working on their undergraduate thesis caused psychological impact called stress. The researcher was intended to find out whether any roles of the Qur'an as a guideline for Muslims reducing the stress level. It is a field research with a quantitative experimental approach which used two groups(pre-test-post-test) design with two variables: training of meaning and reading verses of the Qur'an (X) and stress level (Y). The subjects were 12 students divided into 6 students in each of experimental and control group. The experimental group used paired samples $t$-test and got a $p$-value of $0,035, p<0,05$ means there was a difference of scores between pretest and post-test. The control group obtained a $p$-value of $0.849, p<0.05$ means there was no difference in scores between pretest and post-test. Based on the results of different test analysis using independent samples $t$-test obtained the p-value of 0.000 is smaller than 0.01 showed that there is a significant difference in stress level between the two groups. The results indicate that the training of meaning and reading of Quranic verses can reduce the stress level of students who are working on an undergraduate thesis in the Islamic Psychology Study Program of the State Islamic University of Antasari Banjarmasin.
\end{abstract}

Keywords: Training; the Qur'an; Stress Level; Undergraduate Thesis.

\begin{abstract}
Abstrak
Penelitian ini berawal dari tekanan-tekanan tugas skripsi yang dirasakan mahasiswa lalu menimbulkan dampak psikologis salah satunya yaitu stres. Terkait dengan dampak itu lalu adakah peran Alquran sebagai pedoman utama umat Islam untuk menurunkan tingkat stres tersebut. Penelitian ini adalah penelitian lapangan dengan pendekatan eksperimen. Penelitian ini menggunakan desain two group pre-test post-test design. Variabel dalam penelitian ini ada dua yakni pelatihan pemaknaan dan pembacaan ayat-ayat Alquran $(X)$ dan tingkat stres $(Y)$. Subjek berjumlah 12 mahasiswa pada dua kelompok, enam orang kelompok eksperimen dan enam orang kelompok kontrol. Hasil penelitian menggunakan uji beda pada kelompok eksperimen menggunakan paired samples t-test didapat nilai $p=0,035, p<0,05$ artinya ada perbedaan skor antara pretest dan posstest. Sedangkan pada kelompok kontrol didapat nilai $\mathrm{p}=$ $0,849, \mathrm{p}<0,05$ artinya tidak ada perbedaan skor antara pretest dan posstest. Berdasarkan hasil

${ }^{1}$ Tulisan ini di dasarkan skripsi penulis pada Program Studi Psikologi Islam Fakultas Ushuluddin dan Humaniora Universitas Islam Negeri Antasari Banjarmasin

${ }^{2}$ Korespondensi untuk tulisan ditujukan kepada email havizanshori@gmail.com
\end{abstract}


analisis uji beda dengan menggunakan independent samples t-test didapat nilai $\mathrm{p}$ 0,000 yang lebih kecil dari 0,01, artinya ada perbedaan tingkat stres yang signifikan antara kelompok eksperimen dan kelompok kontrol. Hasil itu menunjukkan bahwa pelatihan pemaknaan dan pembacaan ayat-ayat Alquran dapat menurunkan tingkat stres mahasiswa yang sedang mengerjakan skripsi di program studi Psikologi Islam Universitas Islam Negeri Antasari Banjarmasin.

Kata kunci: Pelatihan; Alquran; Tingkat Stres; Skripsi.

\section{Pendahuluan}

Skripsi adalah karya tulis ilmiah mahasiswa yang wajib diselesaikan untuk melengkapi syarat mendapatkan gelar sarjana (Dalman, 2013). Skripsi yang disusun oleh mahasiswa juga diharapkan bermanfaat bagi masyarakat secara umum. Mahasiswa yang menyusun skripsi dituntut untuk dapat mengatasi tekanan dalam proses belajar yang berlangsung secara individual sehingga tuntutan akan belajar mandiri juga semakin besar, walaupun tetap dibimbing oleh dosen pembimbing skripsi. Peran dosen dalam pembimbingan skripsi hanya bersifat membantu mengatasi kesulitan yang ditemui mahasiswa dalam penyusunan skripsi (Gunawati, Hartati, \& Listiara, 2010).

Tekanan-tekanan dalam penyusunan skripsi akan menimbulkan dampak psikologis, salah satunya adalah stres. Penelitian yang dilakukan Abdur Rozaq, bahwa tingkat stres mahasiswa mencapai 69.23 persen dalam tingkat sedang, dengan beberapa gejala yaitu mudah tersinggung, produktivitas menurun dan sulit mengambil keputusan (Rozak, 2014). Penelitian lain juga yang dilakukan Adhe Primadita terhadap 31 mahasiswa yang sedang mengerjakan skripsi bahwa 28 persen mahasiswa mengalami stres dalam kategori berat, 28 persen dalam kategori sedang, dan sisanya sebanyak 48 persen dalam kategori sedang (Pramedite, 2017).

Studi pendahuluan yang dilakukan peneliti juga mendapati hal serupa, subjek berinisial HR salah satu mahasiswa Program Studi Psikologi Islam mengatakan bahwa selama proses skripsi dia merasakan tekanan yang lebih berat dari semester sebelumnya di masa kuliah, tuntutan waktu dan tuntutan lingkungan sekitar seperti keluarga dan dosen membuat HR selalu memikirkan skripsi yang mengakibatkan tidur lebih larut dari biasanya (HR, 2017). Mahasiswa Program Studi Psikologi Islam lain yang sedang mengerjakan skripsi berinisial MY, juga mengalami hal sama yaitu sulit tidur karena selalu memikirkan skripsi, bahkan sulit 
makan selama masa proses penyusunan skripsi (MY, 2017). Perilaku mahasiswa yang merasakan cemas, tidak berdaya, gelisah, suasana hati yang mudah berubah, bahkan sampai mengalami sulit makan dan tidur itulah yang gejala stres (Handoyo, 2012). Data-data tersebut menunjukkan sudah jelas bahwa tugas skripsi yang memang harusnya wajib diselesaikan malah memunculkan tekanan dan tuntutan melebihi apa yang dibayangkan dan secara tidak langsung menyebabkan stres pada mahasiswa.

Stres merupakan suatu keadaan psikologis individu yang disebabkan oleh tuntutantuntutan yang terlalu banyak yang bersumber dari kondisi internal maupun lingkungan eksternal sehingga terancam kesejahteraannya (Mumtahinnah, 2014). Hans Seyle mendefinisikan stres yaitu respon yang tidak spesifik dari tubuh terhadap tuntutan yang diterimanya, suatu fenomena universal dalam kehidupan sehari-hari dan tidak dapat dihindari, setiap orang pasti mengalaminya (Pedak, 2009). Sedangkan Vincent Cornelli berpendapat bahwa stres adalah gangguan pada tubuh dan pikiran yang disebabkan oleh perubahan dan tuntutan kehidupan (Pedak, 2009). Sedangkan menurut agama tidak memandang stres (yang disebut sebagai ujian atau bala) sebagai sesuatu yang negatif. Islam memandangnya sebagai sesuatu yang diperlukan dalam perkembangan manusia. Lalu dengan stres inilah kita dinilai apakah kita termasuk orang yang bersabar atau tidak (Hasan, 2008). Firman Allah SWT yang menjelaskan tentang hal ini tercantum dalam Q.S. al-Ma'arij/70: 19-21.

Beberapa pendekatan terapi dalam psikologi bermacam-macam dalam mengatasi masalah psikologi atau psikopatologi dalam konteks ini adalah stres, mulai dari terapi psikoanalisa yang berfokus pada yang disebut ego dalam ilmu psikologi, juga ada terapi behavioristik yang berfokus pada prinsip belajar agar memodifikasi perilaku, lalu terapi kognitif merupakan teknik keyakinan maladatif untuk mengganti interpretasi yang lebih realistis dan berbagai macam pendekatan terapi lainnya seperti terapi teori humanistik serta terapi Islam.

Terkait dengan tingkat stres yang dirasakan mahasiswa dalam menyusun skripsi, adakah peran religiusitas terhadap penurunan tingkat stres tersebut? Hasil penelitian George dkk dalam Aning Azzahra, menunjukkan bahwa keyakinan dan kegiatan keagamaan dapat berperan sebagai pencegah dan penyembuh terhadap stres (Azzahra, 2013). Selain itu, dengan berkembangnya aliran humanistik dan bahkan muncul aliran Transpersonal, tema 
Psikopatologi erat dikaitkan dengan dimensi spritualitas dan religiusitas, Psikoterapi intervensi religius menggunakan tradisi dan praktik agama sebagai media untuk proses penyembuhan (healing) (Mar;ati, 2016). Praktek agama dalam Islam seperti sholat, puasa, dzikir dan membaca Alquran dan sebagainya, sedangkan pada agama lain misalnya berdoa, meditasi, relaksasi dan sebagainya. Allah SWT telah menjelaskan bahwa Alquran diturunkan mengandung syifa (penyembuhan), Alquran mempunyai kekuatan untuk menangani dan menyembuhkan tekanan jiwa (Jalaluddin, 2002), hal tersebut dipaparkan firman Allah SWT dalam Q.S. Yunus/10: 57.

Berkaitan dengan media psikoterapi religius terhadap stres, Alquran dapat digunakan sebagai intervensi untuk menurunkan tekanan psikologis karena banyak ayat-ayat Alquran yang berhubungan dengan dinamika kejiwaan manusia yang secara teoritik dapat dijadikan dasar acuan. Alquran juga mengandung banyak hikmah dan nasehat, baik dengan konsep pahala, hukuman maupun kisah yang semuanya dapat menjadi pelajaran guna memperbaiki hati dengan pemaknaan (al-Zahrani, 2005). Salah satunya Alquran datang konsep kesabaran. Dengan kesabaran, Alquran mengajak manusia untuk menyadari segala sesuatunya ada di tangan Allah SWT SWT. Sebagaimana fiman Allah SWT. dalam Q.S. al-Baqarah/2 : 155-156. Kesabaran juga akan mengarahkan manusia kepada tindak tawakal. Dengan bertawakal Allah SWT akan mencukupkan keperluannya yang telah mengadakan ketentuan bagi setiap sesuatu, dalam Q.S. ath-Thalaq/65: 3. Selain bersabar dan bertawakal, anjuran lapang dada dalam menanggulangi stres bahwa ada kemudahan sesudah kesulitan juga sebaliknya, tersirat dalam Q.S. al-Insyirah/94: 1-4.

Media membaca dan mendengarkan Alquran ini terbukti menurunkan tingkat stres pada beberapa penelitian, hasil penelitian yang dilakukan Aning Azzahra menunjukkan bahwa pembacaan dan pemaknaan surah Al-Insyirah cukup efektif menurunkan stres mahasiswa yang sedang mengerjakan skripsi (Azzahra, 2013). Hasil penelitian lain yang dilakukan Iis Fitriatun bahwa mendengarkan ayat-ayat Alquran dapat menurunkan stres pasien kanker serviks dan dapat menjadi terapi tambahan terhadap pasien tersebut (Fitriatun, 2014). Konsep yang ditawarkan Alquran tersebut yang menjadi acuan peneliti untuk membuat sebuah intervensi atau pelatihan untuk menurunkan tingkat stres mahasiswa yang sedang mengerjakan skripsi. 
Berdasarkan uraian tersebut, peneliti tertarik mengkaji lebih dalam dengan melakukan sebuah penelitian yaitu dengan memberikan perlakuan berupa pelatihan kepada mahasiswa yang sedang mengerjakan skripsi. Dengan tujuan untuk mengetahui tingkat stres pada mahasiswa yang sedang skripsi lalu mengetahui apakah pelatihan ayat-ayat Alquran dapat menurunkan tingkat stres tersebut serta mengetahui perbedaan antara tingkat stres mahasiswa yang diberikan pelatihan ayat-ayat Alquran dan yang tidak diberikan pelatihan.

Hipotesis dalam penelitian ini yaitu: terdapat pengaruh signifikan antara pelatihan pemaknaan dan pembacaan ayat-ayat Alquran untuk menurunkan tingkat stres mahasiswa Program Studi Psikologi Islam di Universitas Islam Negeri Antasari Banjarmasin yang sedang mengerjakan skripsi.

\section{Metode}

Penelitian ini menggunakan pendekatan kuantitatif eksperimental. Penelitian ini menggunakan desain two group pre-test post-test design, yakni peneliti memberikan pretest kepada kelompok eksperimen dan kelompok kontrol, kemudian peneliti memberikan perlakuan atau intervensi kepada kelompok eksperimen yang menjadi subjek dalam penelitian ini. Sedangkan kelompok kontrol tidak diberikan perlakuan. Setelah intervensi dilakukan, peneliti akan melakukan post-test kepada kelompok eksperimen dan kelompok kontrol untuk dapat dianalisa lebih lanjut. Kelompok kontrol merupakan waiting list pelatihan yang akan diberikan perlakuan berupa pelatihan yang sama dengan kelompok eksperimen sebagai bentuk tanggung jawab moral peneliti.

Subyek penelitian ini adalah mahasiswa Program Studi Psikologi Islam yang mengalami stres tingkat sedang dan tinggi berdasarkan skala yang sedang menyusun skripsi di Universitas Islam Negeri Antasari Banjarmasin dan bersedia menjadi subjek dengan mengisi lembar informed concerned.

Sebelum ditentukan untuk menjadi subjek penelitian, jumlah populasi mahasiswa Program Studi Psikologi Islam yang sedang mengerjakan skripsi adalah sebagai berikut. 
Tabel 1

Jumlah Populasi Mahasiswa Program Studi Psikologi Islam yang Sedang Mengerjakan Skripsi

\begin{tabular}{cccc}
\hline Tahun Angkatan/ & $2014 /$ & $2013 /$ & Populasi \\
Semester & VI & VIII & \\
\hline Laki-laki & 21 & 7 & \\
Perempuan & 47 & 8 & 83 \\
\hline Total & 68 & 15 & \\
\hline
\end{tabular}

Sampel dari penelitian ini adalah mahasiswa Program Studi Psikologi Islam di Universitas Islam Negeri Antasari Banjarmasin yang berada antara semester 6-8 dan sedang menyusun skripsi. Teknik sampling yang digunakan dalam penelitian ini adalah teknik sampel purposive.

Sedangkan objek dalam penelitian ini ada dua variabel yaitu Variabel eksperimental (X) : Pelatihan Pemaknaan dan Pembacaan Ayat-ayat Alqur'an Variabel terikat $(\mathrm{Y}) \quad$ : Tingkat stres

Pengumpulan data dalam penelitian ini hanya menggunakan satu skala yakni perceived stress scale (PSS-10), karena dalam penelitian ini peneliti melakukan intervensi kepada subjek, dengan memberikan pelatihan pemaknaan dan pembacaan ayat-ayat Alquran. Instrumen yang digunakan dalam penelitian hanya satu skala, yakni perceived stress scale. Perceived Stress Scale (PSS-10) merupakan self questionnaire yang terdiri dari 10 pertanyaan dan dapat mengevaluasi tingkat stres beberapa bulan yang lalu dalam kehidupan subjek penelitian. Skor PSS diperoleh dengan reversing respons (sebagai contoh, $0=4,1=3,2=2,3=1,4=0$ ) terhadap empat soal yang bersifat positif (pertanyaan no 4, 5, 7 \& 8) dan menjumlahkan skor masing-masing. Soal dalam perceived stress scale ini akan menanyakan tentang perasaan dan pikiran responden dalam satu bulan terakhir. Perceived stress scale dalam bahasa Indonesia telah dinyatakan valid dan reliabel dengan nilai koefisien cronbach alpha sebesar 0,96 (Pin, 2010).

Teknik pengolahan data dalam penelitian ini dimulai dari proses editing, skoring, dan tabulating. Analisis data utama pada penelitian ini adalah analisis statistik, dengan memakai uji paired t-test (uji-t) menggunakan IBM SPSS Statistics 22. Selain itu, pada penelitian ini juga menggunakan analisis kualitatif sebagai analisis pendukung berupa wawancara, observasi dan lembar kerja setiap sesi pelatihan. 


\section{H a s i 1}

\section{Pelaksanaan Penelitian}

Screnning Test

Penelitian ini diawali dengan screnning test, yakni pemberian perceived stress scale dengan tujuan mengetahui seberapa banyak mahasiswa Program Studi Psikologi Islam yang mengalami stres sedang dan berat. Screnning test dilakukan pada tanggal 6-8 Juni 2017 dengan cara penyebaran skala di sekitar Perguruan Tinggi, kepada 30 mahasiswa Program Studi Psikologi Islam angkatan 2014 dan 13 mahasiswa Program Studi Psikologi Islam angkatan 2013, jumlah keseluruhan mahasiswa Program Studi Psikologi Islam yang mengisi perceived stress scale saat pretest berjumlah 43 orang.

Setelah melaksanaan screnning test, selanjutnya melakukan model kategorisasi data penelitian berdasarkan hasil skor perceived stress scale. Hasil skor tingkat stres pada mahasiswa Program Studi Psikologi Islam yang sedang menyusun skripsi sebagai berikut.

\section{Tabel 2}

Kategori Tingkat Stres Mahasiswa Program Studi Psikologi Islam yang Sedang Mengerjakan Skripsi

\begin{tabular}{ccccc}
\hline No. & Skor & Frekuesi & Relatif (persen) & Kategori \\
\hline 1. & $1-14$ & 8 & 18 persen & Ringan \\
2. & $15-26$ & 34 & 79 persen & Sedang \\
3. & $>26$ & 1 & 3persen & Berat \\
\hline \multicolumn{2}{r}{ Jumlah } & 43 & 100 persen & \\
\hline
\end{tabular}

\section{Pretest}

Pretest pada penelitian adalah data yang diambil dari data screnning test. Dari jumlah 43 mahasiswa yang mengikuti screnning test maka yang diambil peneliti untuk diintervensi atau diberikan perlakuan adalah mahasiswa yang masuk dalam kategori sedang dan berat yaitu 34 mahasiswa dalam kategori sedang dan satu mahasiswa dalam kategori berat sehingga berjumlah 35 orang. Dari 35 orang tersebut yang bersedia menjadi subjek penelitian berjumlah 12 orang, lalu dibagi dalam dua kelompok, yaitu kelompok eksperimen dan kelompok kontrol. 
Kelompok eksperimen berjumlah enam mahasiswa dan kelompok kontrol berjumlah enam orang. Adapun jumlah skor pretest tingkat stres mahasiswa pada kelompok eksperimen dan kelompok kontrol adalah sebagai berikut:

Tabel 3

Hasil Skor Pretest Tingkat Stres Kelompok Eksperimen

\begin{tabular}{llll}
\hline Kelompok & Subjek & Skor pretest & Kategori \\
\hline \multirow{5}{*}{ Eksperimen } & A & 28 & Berat \\
& B & 22 & Sedang \\
& C & 21 & Sedang \\
& D & 20 & Sedang \\
& E & 18 & Sedang \\
& F & 15 & Sedang \\
\hline
\end{tabular}

Tabel 4

Hasil Skor Pretest Tingkat Stres Kelompok Kontrol

\begin{tabular}{llll}
\hline Kelompok & Subjek & Skor pretest & Kategori \\
\hline \multirow{4}{*}{ Kontrol } & A & 26 & Sedang \\
& B & 20 & Sedang \\
& C & 20 & Sedang \\
& D & 19 & Sedang \\
& E & 18 & Sedang \\
& F & 17 & Sedang \\
\hline
\end{tabular}

Perlakuan atau Pelatihan

Setelah melakukan tahap pretest, kemudian peneliti memberikan intervensi berupa pelatihan kepada kelompok eksperimen, sedangkan kelompok kontrol tidak diberikan perlakuan tetapi sebagai waiting list. Berikut adalah rundown acara pelatihan:

Tabel 5

Pelaksanaan Pelatihan Pemaknaan Ayat-Ayat Alquran

\begin{tabular}{lll}
\hline No. & \multicolumn{1}{c}{ Sesi } & \multicolumn{2}{c}{ Keterangan } \\
\hline 1. & Materi I “Kelapangdadaan” & $\begin{array}{l}\text { Materi, game, video dan } \\
\text { relaksasi }\end{array}$ \\
\hline
\end{tabular}




\begin{tabular}{|c|c|c|}
\hline 2. & $\begin{array}{c}\text { Materi II "Setiap Kesulitan Ada } \\
\text { Kemudahan" }\end{array}$ & Materi dan diskusi \\
\hline 3. & Ishoma & Istirahat, sholat dan makan \\
\hline 4. & Materi III “Etos Kerja” & Materi, game dan lembar kerja \\
\hline 5. & Murattal Alquran & $\begin{array}{l}\text { Tadarus surah Al-Insyirah agar } \\
\text { lebih terinternalisasi }\end{array}$ \\
\hline 6. & Materi IV “Kesabaran” & Materi dan game \\
\hline 7. & Materi V"Tawakkal” & $\begin{array}{l}\text { Materi, penayangan video dan } \\
\text { role play }\end{array}$ \\
\hline 8. & Refleksi Diri dan Evaluasi & Persentasi dan diskusi \\
\hline
\end{tabular}

\section{Posttest}

Tahap terakhir yang dilakukan peneliti setelah intervensi adalah melakukan posttest kepada kelompok eksperimen dan kelompok kontrol, sesi posttest untuk kelompok eksperimen dan kelompok kontrol dilakukan setelah kegiatan pelatihan selesai pada hari Jum'at tanggal 7 Juli 2017. Berdasarkan skoring dari hasil posttest yang dilakukan dengan menggunakan kategorisasi seperti perhitungan pretest, maka didapatkan hasil sebagai berikut:

Tabel 6

\section{Hasil Skor Posttest Tingkat Stres Kelompok Eksperimen}

\begin{tabular}{llll}
\hline Kelompok & Subjek & Skor pretest & Kategori \\
\hline & A & 14 & Ringan \\
Eksperimen & B & 15 & Sedang \\
& C & 16 & Sedang \\
& D & 16 & Sedang \\
& E & 16 & Sedang \\
& F & 14 & Ringan \\
\hline
\end{tabular}




\section{Hasil Skor Posttest Tingkat Stres Kelompok Kontrol}

\begin{tabular}{llll}
\hline Kelompok & Subjek & Skor pretest & Kategori \\
\hline \multirow{4}{*}{ Kontrol } & A & 22 & Sedang \\
& B & 20 & Sedang \\
& C & 21 & Sedang \\
& D & 19 & Sedang \\
& E & 20 & Sedang \\
& F & 17 & Sedang \\
\hline
\end{tabular}

\section{Analisa Kuantitatif}

Deskripsi statistik digunakan untuk menganalisis data dengan cara mendeskripsikan atau menggambarkan data yang diperoleh sebagaimana adanya tanpa bermaksud membuat kesimpulan yang berlaku untuk umum atau generalisasi.

Tabel 8

Hasil Skor Pretest Dan Posttest Tingkat Stres Kelompok Eksperimen Dan Kelompok Kontrol

\begin{tabular}{llllll}
\hline Kelompok & Subjek & Skor & Kategori & Skor & Kategori \\
\hline \multirow{6}{*}{ Eksperimen } & & Pretest & & Posttest & \\
& A & 28 & Berat & 14 & Rendah \\
& B & 22 & Sedang & 15 & Sedang \\
& C & 21 & Sedang & 16 & Sedang \\
& E & 20 & Sedang & 16 & Sedang \\
& F & 18 & Sedang & 16 & Sedang \\
& & & Sedang & 14 & Rendah \\
\hline \multirow{5}{*}{ Kontrol } & A & 26 & Sedang & 22 & Sedang \\
& B & 20 & Sedang & 20 & Sedang \\
& C & 20 & Sedang & 21 & Sedang \\
& D & 19 & Sedang & 19 & Sedang \\
& E & 18 & Sedang & 20 & Sedang \\
& F & 17 & Sedang & 17 & Sedang \\
\hline
\end{tabular}

Berdasarkan deskripsi data subjek penelitian yang diperoleh, maka dapat dideskripsikan secara statistik dapat dilihat sebagai berikut: 
Tabel 9

Deskripsi Statistik Subjek Penelitian

\begin{tabular}{lllll}
\hline & \multicolumn{2}{l}{ Kelompok Eksperimen } & \multicolumn{2}{l}{ Kelompok Kontrol } \\
\hline & Pretest & posttest & Pretest & Posttest \\
$\mathrm{N}$ & 6 & 6 & 6 & 6 \\
$\mathrm{SD}$ & 4,366 & 0,98 & 3,162 & 1,722 \\
Mean & 20,666 & 15,166 & 20,000 & 19,833 \\
Minumum & 15 & 14 & 17 & 17 \\
Maximum & 28 & 16 & 26 & 22 \\
\hline
\end{tabular}

Analisis data skor kelompok eksperimen menunjukkan ada penurunan rata-rata sebesar 5,500 (pretest $=20,666$ dan posttest $=15,166$ ). Sedangkan analisis data skor kelompok kontrol menunjukkan suatu penurunan rata-rata yang relatif kecil yaitu 0,167 (pretest $=20$ dan posttest $=$ 19,833).

Analisis data yang digunakan untuk menguji hipotesis dalam penelitian ini menggunakan uji-t yaitu dengan paired samples-test, yaitu analisis dengan melibatkan pengukuran subjek yang sama terhadap suatu pengaruh atau dala konteks penelitian ini adalah perlakuan yang diberikan dengan bantuan IBM SPSS Statistics 22.

Tabel 10

Uji Beda Pada Kelompok Eksperimen Pretest-Posttest Paired Samples Test

\begin{tabular}{|c|c|c|c|c|c|c|c|c|}
\hline & \multirow[t]{2}{*}{ Mean } & \multirow{2}{*}{$\begin{array}{c}\text { Std. } \\
\text { Deviation }\end{array}$} & \multirow{2}{*}{$\begin{array}{l}\text { Std. } \\
\text { Error } \\
\text { Mean }\end{array}$} & \multicolumn{2}{|c|}{$\begin{array}{c}95 \% \text { Confidence } \\
\text { interval of the } \\
\text { differrence }\end{array}$} & \multirow[t]{2}{*}{$t$} & \multirow[t]{2}{*}{$d f$} & \multirow[t]{2}{*}{$\begin{array}{l}\text { Sig (2- } \\
\text { tailed) }\end{array}$} \\
\hline & & & & Lower & Upper & & & \\
\hline $\begin{array}{l}\text { Pretest- } \\
\text { Posttest }\end{array}$ & 5,5 & 4,679 & 1,91 & 0,588 & 10,411 & 2,879 & 5 & 0,035 \\
\hline
\end{tabular}

Tabel 11

Uji Beda Pada Kelompok Kontrol Pretest-Posttest Paired Samples Test 


\begin{tabular}{|c|c|c|c|c|c|c|c|c|}
\hline & \multirow[t]{2}{*}{ Mean } & \multirow{2}{*}{$\begin{array}{c}\text { Std. } \\
\text { Deviation }\end{array}$} & Std. & \multicolumn{2}{|c|}{$\begin{array}{c}\text { interval of the } \\
\text { differrence }\end{array}$} & \multirow[t]{2}{*}{$t$} & \multirow[t]{2}{*}{$d f$} & \multirow[t]{2}{*}{$\begin{array}{l}\text { Sig (2- } \\
\text { tailed) }\end{array}$} \\
\hline & & & $\begin{array}{l}\text { Error } \\
\text { Mean }\end{array}$ & Lower & Upper & & & \\
\hline $\begin{array}{l}\text { Pretest- } \\
\text { Posttest }\end{array}$ & 0,166 & 2,041 & 0,833 & $-1,975$ & 2,308 & 0,2 & 5 & 0,849 \\
\hline
\end{tabular}

Uji beda yang dilakukan pada kelompok eksperimen mendapatkan nilai $\mathrm{t}=2,879$ dan $\mathrm{p}=$ 0,035, $\mathrm{p}<0,05$, artinya ada perbedaan skor tingkat stres pada mahasiswa sedang mengerjakan skripsi yang signifikan antara sebelum dan sesudah mengikuti pelatihan ayat-ayat Alquran. Sedangkan pada kelompok kontrol didapatkan nilai $t=0,2$ dan $p=0,849, p>0,05$, artinya tidak ada pengaruh yang signifikan tingkat stres pada mahasiswa sedang mengerjakan skripsi.

Selanjutnya dilakukan uji beda pengaruh pelatihan pemaknaan dan pembacaan ayat-ayat Alquran antara kelompok eksperimen dan kelompok kontrol menggunakan IndependentSamples T Test, lalu didapatkan hasil berikut.

Tabel 12

Uji Pengaruh Pelatihan Pemaknaan Dan Pembacaan Ayat-Ayat Alquran Antara Kelompok Eksperimen Dan Kelompok Kontrol (Independent-Samples T Test)

\begin{tabular}{ccccccc}
\hline & Kelompok & N & Mean & $\begin{array}{c}\text { Std. } \\
\text { Deviasi }\end{array}$ & T & $\begin{array}{c}\text { Sig. (2- } \\
\text { tailed) }\end{array}$ \\
\hline $\begin{array}{c}\text { Tingkat } \\
\text { Stres }\end{array}$ & Eksperimen & 6 & 15,166 & 0,983 & $-5,764$ & 0,000 \\
\hline
\end{tabular}

Uji beda ini dilakukan untuk mengetahui ada tidaknya perbedaan pengaruh tingkat stres sebelum dan sesudah pelatihan pemaknaan dan pembacaan ayat-ayat Alquran pada kelompok eksperimen dan kelompok kontrol. Perhitungan $\mathrm{t}$ didasarkan pada equal varians assummed (diasumsikan kedua varian sama) menghasilkan $t=-5,764$ dan $p=0,000, p<0,01$, artinya adalah ada perbedaan tingkat stres yang sangat signifikan antara kelompok eksperimen dan kelompok kontrol. Sehingga hipotesis penelitian ini dapat diterima.

\section{Pembahasan}

Hasil penelitian menunjukkan bahwa pelatihan pemaknaan dan pembacaan ayat-ayat Alquran dapat menurunkan tingkat stres mahasiswa Program Studi Psikologi Islam yang 
sedang mengerjakan skripsi. Hal ini dikarenakan dalam pelatihan, peneliti menggunakan surah Al-Insyirah sebagai salah satu materi pokok pada pelatihan ini, yang mana dalam surah AlInsyirah ini mengandung tiga aspek, yaitu aspek kelapangdadaan, yaitu aspek dibalik kesulitan ada kemudahan dan aspek etos kerja. Dalam surah Al-Insyirah mengandung aspek kelapangdadaan yang menurut Fuad Nashori adalah suatu kondisi psikospritual yang ditandai oleh kemampuan menerima berbagai kenyataan yang tidak menyenangkan dengan tenang dan tidak terkendali. Orang yang lapang dada memiliki kekuatan dalam jiwanya untuk bertahan dan tidak berputus asa ketika menghadapi berbagai situasi yang secara objektif tidak menyenangkan baik psikis maupun fisik. Semakin tinggi kelapangdadaan seseorang seseorang semakin mampu ia menghadapi realitas yang beragam, termasuk yang tidak menyenangkan (Nashori, 2008). Dalam pelatihan ini subjek dilatih untuk berlapang dada antara lain mengerti bahwa hidup adalah ujian dari Allah SWT dan berfungsi untuk menaikkan derajat hamba-Nya, menyadari masalah yang dihadapinya, menerima kenyataan dan ikhlas melepaskan masalah.

Selanjutnya Al-Insyirah juga mengandung makna di balik kesulitan ada kemudahan. Pada makna ini ada larangan untuk berputus asa, harus selalu berharap, ridha, sabar serta selalu berpikir positif, percaya bahwa Allah SWT memberikan jalan kemudahan bagi setiap hambaNya yang sedang dihampiri kesulitan. Betapapun beratnya kesulitan yang dihadapi, pasti dalam celah-celah kesulitan itu terdapat kemudahan-kemudahan. Ayat ini juga memesankan agar manusia berusaha menemukan segi-segi positif yang dapat dimanfaatkan dari setiap kesulitan. Ayat ini seolah-olah berpesan agar setiap manusia mencari peluang pada setiap tantangan dan kesulitan yang dihadapi (Shihab, 2002). Pada sesi pelatihan ini subjek dilatih agar selalu berpikir positif, selalu bergembira dan tidak berputus asa dalam membijaki sebuah masalah. Dengan demikian dapat disimpulkan bahwa aspek ini mampu mengubah kognitif subjek agar lebih positif sehingga dapat mengurangi stres dalam mengerjakan skripsi.

Etos kerja adalah aspek lainnya yang ada dalam surah Al-Insyirah ayat 7-8, Toto Tasmara menyatakan bahwa etos kerja bagi seorang muslim adalah suatu upaya yang sungguhsungguh, dengan menggerakkan seluruh tenaga, pikiran dan zikirnya kepada Allah SWT (Tasmara, 1995), dapat mengelola waktu dan tidak melalaikan suatu tugas sesudah tugas yang lainnya selesai, pada sesi ini subjek diberikan permainan bagaimana dapat menyelesaikan tugas 
dengan mengelola waktu dengan baik dan memperhatikan setiap petunjuk dalam sebuah tugas, sesi ini bertujuan agar subjek mendapatkan semangat baru dalam mengerjakan tugas, terlebih pada tugas akhir mahasiswa yaitu skripsi.

Selain surah Al-Insyirah, pada pelatihan ini peneliti juga memasukkan surah Al-Baqarah ayat 155-157 berbicara tentang kesabaran yang mana ayat tersebut dapat diambil pemahaman, bahwa jika seseorang dengan penuh kesadaran sudah mengatakan: sesungguhnya kita milik Allah SWT dan kepada-Nya lah kita akan kembali saat mendapat musibah, maka ia akan mendapat kabar gembira, Berawal dari sinilah maka manusia yang bersabar ketika tertimpa musibah tidak akan mengalami stres (Najati, 1985). Penelitian Luluk Dina Islamiyah membuktikan bahwa terapi sabar dapat mengelola stres dengan baik bahkan dapat mengurangi stres tersebut (Islamiyah, 2017). Dalam sesi pelatihan aspek sabar, subjek dilatih agar mengerti bahwa konsep sabar bisa dilakukan dengan cara ikut merasakan apa yang orang rasakan, dan juga mengabaikan sesuatu yang orang lain anggap penting, karena suatu saat setiap orang pasti merasakan hal sama, lalu rasa stres yang dirasa subjek cukup tinggi akan berkurang setelah mengerti konsep kesabaran pada ayat tersebut.

Aspek terakhir yang dimasukkan peneliti adalah aspek tawakkal yang ada dalam surah Ath-Thalaq ayat 3, Al-Qusyairi mengatakan bahwa tawakkal tempatnya didalam hati, dan timbulnya gerak dalam perbuatan tidak mengubah tawakkal yang terdapat dalam hati itu. Hal itu terjadi karena setelah hamba meyakini bahwa segala ketentuan hanya didasarkan pada ketentuan Allah SWT. Mereka menganggap jika menemui kesulitan maka yang demikian itu sebenarnya takdir Allah SWT (Najati, 2007). Cara berpikir negatif yang menekankan kepada persepsi stres sebagai yang dan merugikan, perlu diubah menjadi berpikir positif yang menekankan kepada pengertian stres sebagai sesuatu yang tidak perlu dicemaskan, karen janji Allah SWT dalam ayat tersebut adalah akan memberikan rezeki dari hal tidak pernah diduga oleh sebelumnya. Dalam pelatihan ini diberikan sesi role play yang mempraktikkan rasa tawakkal kepada segala sesuatu dalam kehidupan sehari-hari, pada konteks ini adalah menghadapi skripsi, karena dengan menyerahkan semuanya kepada Allah SWT dan selalu berikhtiar sehingga rasa beban yang berat menurun menjadi ringan serta rasa stres yang tinggipun akan berkurang. 
Selain itu, berdasarkan analisa kualitatif yang peneliti lakukan terhadap subjek dengan cara wawancara dan menganalisis lembar kerja pada saat pelatihan dapat disimpulkan bahwa pelatihan tersebut memberi pengaruh yang sangat baik dalam proses pemahaman dan menjadi faktor pendukung dalam memberikan insight yang hadir dalam proses kognitif subjek. Selain itu, berdasarkan data yang didapat dari insight setiap sesi subjek sudah mampu menerima dan memahami maksud dari tujuan setiap sesi, sehingga mampu menghantarkan subjek pada pemaknaan yang jelas terhadap pelatihan. Maka dari itu, peneliti dapat mengatakan bahwa secara umum semua subjek yang mengikuti pelatihan dalam penelitian ini mampu mencapai dan melakukan semua tujuan yang diharapkan dari tiap sesi pelatihan ini.

Hasil penelitian ini sejalan dengan penelitiannya Anning Azzahra bahwa pemaknaan dan pembacaan surah Al-Insyirah cukup efektif mengurangi tingkat stres mahasiswa yang sedang mengerjakan skripsi (Azzahra, 2013). Pada penelitian lain juga yaitu pada penelitiannya lis Fitriatun ditemukan bahwa pengaruh mendengarkan ayat-ayat Alquran dapat menurunkan stres pada pasien kanker serviks ini punya hubungan yang signifikan (Fitriatun, 2014). Begitu juga dengan penelitian Rela Mar'ati yang fokus pada pelatihan pembacaan dan pemaknaan ayat-ayat Alquran dalam menurunkan tingkat kecemasan santriwati, walaupun berbeda dalam variabel terikat tetapi pelatihan yang dilakukannya cukup efektif dalam menurunkan tekanan psikologis lainnya yaitu kecemasan (Mar;ati, 2016).

\section{Kesimpulan}

Berdasarkan hasil yang diperoleh dalam penelitian ini maka dapat dibuat kesimpulan bahwa setelah intervensi dilakukan atau saat posttest, diperoleh data bahwa adanya penurunan tingkat stres mahasiswa yag sedang mengerjakan skripsi, penurunan skor dari kategori tinggi menjadi kategori sedang dan kategori sedang menjadi kategori rendah yang berarti bahwa pelatihan pemaknaan dan pembacaan ayat-ayat Alquran dapat menurunkan tingkat stres mahasiswa yang sedang mengerjakan skripsi di Program Studi Psikologi Islam Universitas Islam Negeri Antasari Banjarmasin dan itu berarti hipotesis yang diajukan peneliti dapat diterima. 
Untuk peneliti yang ingin membuat penelitian yang serupa maka disarankan agar melakukan follow up hasil perlakuan atau pelatihan pemaknaan dan pembacaan ayat-ayat Alquran kepada subjek penelitian sehingga mengetahui konsistensi dari penurunan tingkat stres tersebut. Hendaknya penelitian selanjutnya agar kiranya untuk melakukan penelitian dengan jumlah subjek yang lebih banyak, agar lebih mudah untuk generalisasi. Terakhir, dalam penelitian yang akan datang juga hendaknya melakukan pelatihan pemaknaan dan pembacaan ayat-ayat Alquran dengan sesi yang lebih banyak dan lebih lama, agar subjek dapat lebih memahami dan lebih menghayati makna isi dari pelatihan tersebut.

\section{Kepustakaan}

al-Zahrani, M. (2005). Konseling Terapi. Jakarta: Gema Insani Press.

Azzahra, A. (2013). Efektivitas Pelatihan Pemaknaan Surat Al-Insyirah Untuk Mengurangi Stres Mahasiswa yang Sedang Mengerjakan Skripsi. Jurnal Intervensi Psikologi, 6(1).

Dalman. (2013). Menulis Karya Ilmiah. Jakarta: Rajawali Press.

Fitriatun, L. (2014). Pengaruh Mendengarkan Ayat-ayat Al-Qur'an terhadap Penurunan Stres Pasien Kanker Serviks (Skripsi). Fakultas Kedokteran Universitas Sebelas Maret, Surakarta.

Gunawati, R., Hartati, S., \& Listiara, A. (2010). Hubungan antara efektivitas komunikasi mahasiswa-dosen pembimbing utama skripsi dengan stres dalam menyusun skripsi pada mahasiswa Program Studi Psikologi Fakultas Kedokteran Universitas Diponegoro. Jurnal Psikologi, 3(2), 93-115.

Handoyo, S. (2012). Stres Pada Masyarakat Surabaya. Stres Pada MAsyarakat Surabaya, 3(12).

Hasan, A. B. P. (2008). Pengantar psikologi kesehatan islami. Jakarta: Rajawali Pers.

HR. (2017, Februari 13). Wawancara Dengan Informan.

Islamiyah, L. D. (2017). Terapi Sabar Dengan Teknik Sufistik (Takhalli, Tahalli, Tajalli) Untuk Mengatasi Stres Seorang Ibu Akibat Sudden Death Pada Anak di Desa Mentaras Dukun Gresik (Skripsi). Fakultas Dakwah dan Komunikasi Universitas Islam Negeri Sunan Ampel, Surabaya.

Jalaluddin, R. (2002). Pengantar Psikologi Agama. Edisi Revisi. Jakarta: Rajawali Press.

Mar;ati, R. (2016). Pengaruh Pembacaan dan Pemaknaan Ayat-ayat Alquran terhadap Penurunan Kecemasan pada Santriwati. Jurnal Penelitian Psikologi, 1(1).

Mumtahinnah, N. (2014). Mumtahinnah, Noviyan. "Hubungan Antara Stres Dengam Agresi Pada Ibu Rumah Tangga Yang Tidak Bekerja,"Jurnal Pendidikan, Fakultas Psikologi Universitas Gunadarma Jakarta, 2014. Jurnal Pendidikan Fakultas Psikologi Universitas Gunadarma.

MY. (2017, Februari 13). Wawancara dengan Informasin.

Najati, M. U. (1985). Alquran dan Ilmu Jiwa. Bandung: Pustaka Pelajar.

Najati, M. U. (2007). Psikologi Qur'an. Solo: Aulia Press.

Nashori, F. (2008). Psikologi Sosial Islami. Bandung: PT Refika Aditama. 
Pedak, M. (2009). Metode Supernol Menaklukkan Stres. Jakarta: PT. Mizan Publika.

Pramedite, A. (2017). Efektivitas Intervensi Terapi Musik Klasik Terhadap Stres dalam Menyusun Skripsi Pada Mahasiswa PSIK UNDIP Semarang (Skripsi). Universitas Diponegoro, Semarang. Diambil dari http://eprints.undip.ac.id/33143/

Rozak, A. (2014). Tingkat Stres Mahasiswa dalam Proses Mengerjakan Skripsi (Skripsi). Fakultas Dakwah dan Ilmu Komunikasi Universitas Islam Negeri Sunan Ampel, Surabaya.

Shihab, M. Q. (2002). Tafsir Al-Misbah: Pesan, Kesan dan Keserasian Al-Qur'an. Jakarta: Lentera Hati.

Pin, T. L. (2010). Hubungan Kebiasaan Berolahraga dengan Tingkat Stres Mahasiswa Fakultas Kedokteran USU angkatan 2008 (Skripsi). Fakultas Kedokteran Universitas Sumatera Utara, Medan.

Tasmara, T. (1995). Etos Kerja Pribadi Muslim. Jakarta: PT. Dana Bhakti Wakaf. 